\title{
Assessment of triasulfuron on weed dynamics and yield of transplanted rice (Oryza sativa L.)
}

\section{Samartha Tewari*}

Department of Agronomy, College of Agriculture, G. B. Pant University of Agriculture and Technology Pantnagar - 263145 (Uttarakhand), India

\section{Rohitashav Singh}

Department of Agronomy, College of Agriculture, G. B. Pant University of Agriculture and Technology Pantnagar - 263145 (Uttarakhand), India

Anil Nath

Department of Agronomy, College of Agriculture, G. B. Pant University of Agriculture and Technology Pantnagar - 263145 (Uttarakhand), India

\section{Deepak Pandey}

Department of Agronomy, College of Agriculture, G. B. Pant University of Agriculture and Technology Pantnagar - 263145 (Uttarakhand), India

*Corresponding author. Email: samarthtewarigbpuat@gmail.com

\section{Abstract:}

A field experiment was managed during kharif season of 2014 in G. B. Pant University of Agriculture and Technology, Pantnagar (Uttarakhand) to assess the outcome of applying dissimilar rates of triasulfuron on the transplanted rice (Oryza sativa L.) associated weeds. Treatments composed of triasulfuron at three different rates, metsulfuron methyl, ethoxysulfuron, 2, 4-D with 2 checks (weed free and untreated). Experiment was carried out in Randomised block Design with 8 treatments and 3 replications. Grassy weeds, broad leaf weeds and sedges were observed during the crop growth period. Triasulfuron at $12 \mathrm{~g} \mathrm{ha}^{-1}$ proved most efficient in controlling weeds at 60 and 90 days after transplanting (DAT) with $44.4 \%$ and $59.6 \%$ WCE respectively. Minimum weed dry matter $(65.1 \mathrm{~g} \mathrm{~m} 2)$ was observed with triasulfuron at $12 \mathrm{~g} \mathrm{ha}^{-1}$. Out of all the herbicidal treatments, triasulfuron at $12 \mathrm{~g} \mathrm{ha}^{-1}$ gave the paramount grain yield of rice (5786 kg ha $\mathrm{kg}^{-1}$ ) which was significantly surpassing all other herbicidal treatments, while it was minimum in metsulfuron methyl at $4 \mathrm{~g} \mathrm{ha}^{-1}\left(4417 \mathrm{~kg} \mathrm{ha}^{-1}\right)$.

Keywords: Triasulfuron, Weed Control Efficiency (WCE), Broad Leaf weeds (BLW), Yield

\section{INTRODUCTION}

Rice is the most salient cereal food crop of the world bestowing prime source of the food energy for more than half of the human population. Asia is the domain of paddy as 60-70 per cent of the energy requirement of two billion people gets fulfilled from rice and its gleaned products (Rekha et al., 2015). It is the crucial crop of India and play important role in our food security concerns and India has achieved self-adequacy in terms of production, chiefly contributed by the five states viz., West Bengal, Uttar Pradesh, Andhra Pradesh, Punjab and Tamil Nadu (Nagarajan and Chinnusamy, 2015). Crop competition with weeds for nutrients, water, light and space is the major concern of today. It has been reckoned that without proper weed management, rice crop could lose its yield by $90 \%$ (Ferrero and Tinarelli, 2007). In India, the problem is peculiarly severe in kharif season due to the ubiquity of snug atmosphere for

\section{Article Info}

DOI:10.31018/jans.v10i3.1861 Received: March 22, 2017

Revised: June 11, 2018

Accepted: July 31, 2018

\section{How to Cite}

Tewari, S. et al. (2018).

Assessment of triasulfuron on weed dynamics and yield of transplanted rice (Oryza sativa L.). Journal of Applied and Natural Science, 10(3): 935 - 938 weed growth. Unremitting use of grassy herbicides in paddy field for the control of troublesome weed like Echinochloa spp. ensued in weed shift towards broad leaf weeds (BLW) and sedges which became problematic and significantly lessened the paddy yield. Opportune control of weeds is absolutely necessary to harvest the potential yield of transplanted rice. Triasulfuron, a post emergence herbicide has been reported for prompt and efficacious control of broad leaf weeds by various researches. The objective of our study was to find out the ideal and optimum dose of triasulfuron $20 \%$ WG for the control of associated weeds in transplanted rice and also to study the effect of different treatments of triasulfuron on weed dynamics.

\section{MATERIALS AND METHODS}

A field experiment was conducted during kharif season of 2014-15 in the G.B. Pant University of 
Tewari, S. et al. / J. Appl. \& Nat. Sci. 10 (3): 935 - 938 (2018)

Agriculture and Technology, Pantnagar, Udham Singh Nagar (Uttarakhand). The research site lies in the tarai belt, $30 \mathrm{~km}$ southern end of foothills of Shivalik range of Himalayas at $29^{\circ} \mathrm{N}$ latitude and $79.3^{\circ} \mathrm{E}$ longitudes and an altitude of $243.83 \mathrm{~m}$ above the mean sea level. The soils of tarai region are developed from calcareous, medium to moderately coarse textured materials under predominant influence of tall vegetation and moderate to well drained conditions. The experiment consisted of 8 treatments, was laid out in randomized block design (RBD) with 3 replications. The aim of blocking randomly was to keep the errors minimum within each group (Cochran and Cox, John Wiley and Sons, Inc., 1957). Treatments consisted of triasulfuron in three different rates i.e. 8,10 and $12 \mathrm{~g} \mathrm{ha}^{-1}$, ethoxysulfuron at $15 \mathrm{~g} \mathrm{ha}^{-1}$, metsulfuron methyl at $4 \mathrm{~g} \mathrm{ha}^{-1}, 2,4-\mathrm{D}$ at $500 \mathrm{~g} \mathrm{ha}^{-}$

1 , weed free and untreated check. Seedlings of certified seeds of rice variety "HKR -47 " were raised in nursery by wet bed method. Twenty five days old seedlings were transplanted in puddled field using two seedlings per hill at the spacing of $20 \mathrm{~cm} \times 10 \mathrm{~cm}$. The experimental field of rice crop was fertilized with $120: 60: 40: 5 \mathrm{~kg} / \mathrm{ha}$ of $\mathrm{N}, \mathrm{P}, \mathrm{K}$ and zinc sulphate, respectively. Herbicides were applied as aqueous medium at the rate of 450 liters of water/hectare with the help of knapsack sprayer fitted with flat fan nozzle. Quadrates methods were used to assess weed species distribution. Weeds falling within the quadrate of $50 \mathrm{~cm}$ $x 50 \mathrm{~cm}\left(0.25 \mathrm{~m}^{2}\right)$ from the area marked for recording observations (Clements, 1905). Weeds falling within the quadrate (species wise) were cut close to the ground surface and dried in the sun and then kept in a hot air oven maintained at $70 \pm 2{ }^{\circ} \mathrm{C}$ till constant dry weight. Weed control efficiency (WCE) of different treatments was calculated on the basis of reduction in dry weight of weeds weighed in treated plots over the weedy check and expressed as percentage. Formula of Mani et al. (1973) was adopted for computing the weed control efficiency.

WCE $(\%)=\frac{\text { WDC }- \text { WDT }}{\text { WDC }} \times 100$ ... Eq. 1

Where, WDC $=$ Weed dry weight in control plot $\left(\mathrm{g} / \mathrm{m}^{2}\right)$

WDT $=$ Weed dry weight in treated plot $\left(\mathrm{g} / \mathrm{m}^{2}\right)$

The gross plot $(3 \mathrm{~m} \times 4.5 \mathrm{~m})$ had 15 rows, out of which only 10 rows were harvested for net plot. Out of 4.5 $\mathrm{m}$ row length $0.5 \mathrm{~m}$ length from both sides were left as border, and the harvesting of net plot of $(2 \mathrm{~m} \times 3.5$ m) $7 \mathrm{~m}^{2}$ area was done manually. Then the weight of grain harvested from the net plot was recorded and converted into $\mathrm{kg} / \mathrm{ha}$.

\section{RESULTS AND DISCUSSION}

Effect on weed density: Grassy weeds dominated over non-grassy weeds at 30,60, 90 and 113 days after transplanting (Figure1). Pavithra and Poonguzhalan (2018) reported that predominant weed species in direct seeded rice and transplanted rice is Echinochloa colona under grasses. Among non-grasses, Ammania baccifera, Commelina benghalensis, and Caesulia axillaris and among sedges Cyperus iria are the most dominant weeds. Contribution of $A$. baccifera in weedy

Table 1. Effect of treatments on dry matter of grassy weeds, broadleaf weeds, sedges, weed density, WCE and rice grain yield

\begin{tabular}{|c|c|c|c|c|c|c|c|c|c|}
\hline Treatments & \multicolumn{2}{|c|}{$\begin{array}{l}\text { Dry matter of } \\
\text { Grassy weeds } \\
\left(\mathrm{g} \mathrm{m}^{-2}\right)\end{array}$} & \multicolumn{2}{|c|}{$\begin{array}{l}\text { Dry matter of } \\
B L W \text { weeds ( } g \\
\mathrm{~m}^{-2} \text { ) }\end{array}$} & \multicolumn{2}{|c|}{$\begin{array}{l}\text { Dry matter of } \\
\text { sedges }\left(\mathrm{g} \mathrm{m}^{-}\right. \\
\left.{ }^{2}\right)\end{array}$} & $\begin{array}{l}\begin{array}{l}\text { Total weed } \\
\text { density } \\
\left(\text { No. } \mathrm{m}^{-2}\right)\end{array} \\
60 \text { DAT }\end{array}$ & 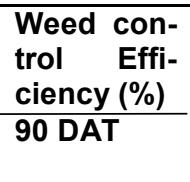 & $\begin{array}{l}\text { Grain } \\
\text { yield } \\
\left(\mathbf{k g}^{-1}\right) \\
\left.\mathrm{ha}^{-1}\right)\end{array}$ \\
\hline $\begin{array}{l}\text { Triasulfuron } 20 \text { WG } \\
@ 8 \mathrm{~g} / \mathrm{ha}\end{array}$ & $\begin{array}{l}8.22 \\
(66.7)\end{array}$ & $\begin{array}{l}9.33 \\
(86.2)\end{array}$ & $\begin{array}{l}2.92 \\
(7.8)\end{array}$ & $\begin{array}{l}3.83 \\
(13.8)\end{array}$ & $\begin{array}{l}2.55 \\
(6.1)\end{array}$ & $\begin{array}{l}3.28 \\
(10.3)\end{array}$ & $9.07(81.3)$ & 39.5 & 4808 \\
\hline $\begin{array}{l}\text { Triasulfuron } 20 \text { WG } \\
@ 10 \mathrm{~g} / \mathrm{ha}\end{array}$ & $\begin{array}{l}7.99 \\
(62.9)\end{array}$ & $\begin{array}{l}8.61 \\
(73.3)\end{array}$ & $\begin{array}{l}1.91 \\
(2.8)\end{array}$ & $\begin{array}{l}2.10 \\
(3.5)\end{array}$ & $\begin{array}{l}2.45 \\
(5.1)\end{array}$ & $\begin{array}{l}3.10 \\
(8.7)\end{array}$ & $8.13(65.3)$ & 54.7 & 5384 \\
\hline $\begin{array}{l}\text { Triasulfuron } 20 \text { WG } \\
\text { @ 12g/ha }\end{array}$ & $\begin{array}{l}7.69 \\
(58.3)\end{array}$ & $\begin{array}{l}8.37 \\
(69.3)\end{array}$ & $\begin{array}{l}1.00 \\
(0.0)\end{array}$ & $\begin{array}{l}1.00 \\
(0.0)\end{array}$ & $\begin{array}{l}2.27 \\
(4.2)\end{array}$ & $\begin{array}{l}2.80 \\
(6.9)\end{array}$ & 7.35(53.3) & 59.6 & 5786 \\
\hline $\begin{array}{l}\text { Metsulfuron methyl } \\
20 \text { WG @ } 4 \text { g/ha }\end{array}$ & $\begin{array}{l}8.73 \\
(75.3)\end{array}$ & $\begin{array}{l}10.14 \\
(102.2)\end{array}$ & $\begin{array}{l}2.28 \\
(4.3)\end{array}$ & $\begin{array}{l}2.94 \\
(7.7)\end{array}$ & $\begin{array}{l}2.88 \\
(7.4)\end{array}$ & $\begin{array}{l}3.92 \\
(14.7)\end{array}$ & $9.13(82.8)$ & 34.0 & 4417 \\
\hline $\begin{array}{l}\text { Ethoxysulfuron } 15 \\
\text { WDG @ } 15 \mathrm{~g} / \mathrm{ha}\end{array}$ & $\begin{array}{l}8.36 \\
(69.1)\end{array}$ & $\begin{array}{l}9.80 \\
(95.2)\end{array}$ & $\begin{array}{l}2.95 \\
(7.9)\end{array}$ & $\begin{array}{l}4.28 \\
(17.5)\end{array}$ & $\begin{array}{l}1.00 \\
(0.0)\end{array}$ & $\begin{array}{l}1.00 \\
(0.0)\end{array}$ & $7.80(59.9)$ & 42.3 & 5043 \\
\hline 2,4-D @ 500 g/ha & $\begin{array}{l}8.44 \\
(70.5)\end{array}$ & $\begin{array}{l}10.15 \\
(102.2)\end{array}$ & $\begin{array}{l}2.46 \\
(5.1)\end{array}$ & $\begin{array}{l}3.18 \\
(9.2)\end{array}$ & $\begin{array}{l}2.60 \\
(5.8)\end{array}$ & $\begin{array}{l}3.58 \\
(11.9)\end{array}$ & $9.21(84.0)$ & 34.6 & 4707 \\
\hline Weed free & $\begin{array}{l}1.00 \\
(0.0)\end{array}$ & $\begin{array}{l}1.00 \\
(0.0)\end{array}$ & $\begin{array}{l}1.0 \\
(0.0)\end{array}$ & $\begin{array}{l}1.0 \\
(0.0)\end{array}$ & $\begin{array}{l}1.00 \\
(0.0)\end{array}$ & $\begin{array}{l}1.00 \\
(0.0)\end{array}$ & $1.00(0.0)$ & 100.0 & 6513 \\
\hline Weedy check & $\begin{array}{l}8.53 \\
(71.8)\end{array}$ & $\begin{array}{l}9.97 \\
(98.6)\end{array}$ & $\begin{array}{l}5.84 \\
(33.2)\end{array}$ & $\begin{array}{l}8.75 \\
(75.7)\end{array}$ & $\begin{array}{l}2.90 \\
(7.5)\end{array}$ & $\begin{array}{l}3.91 \\
(14.5)\end{array}$ & $\begin{array}{l}12.19 \\
(148.0)\end{array}$ & 0.0 & 2705 \\
\hline S.Em \pm & 0.14 & $\begin{array}{l}0.11 \\
0.34\end{array}$ & 0.21 & 0.13 & 0.11 & $\begin{array}{l}0.18 \\
0.52\end{array}$ & 0.25 & - & 57 \\
\hline
\end{tabular}

\# (Original value is in parenthesis). 


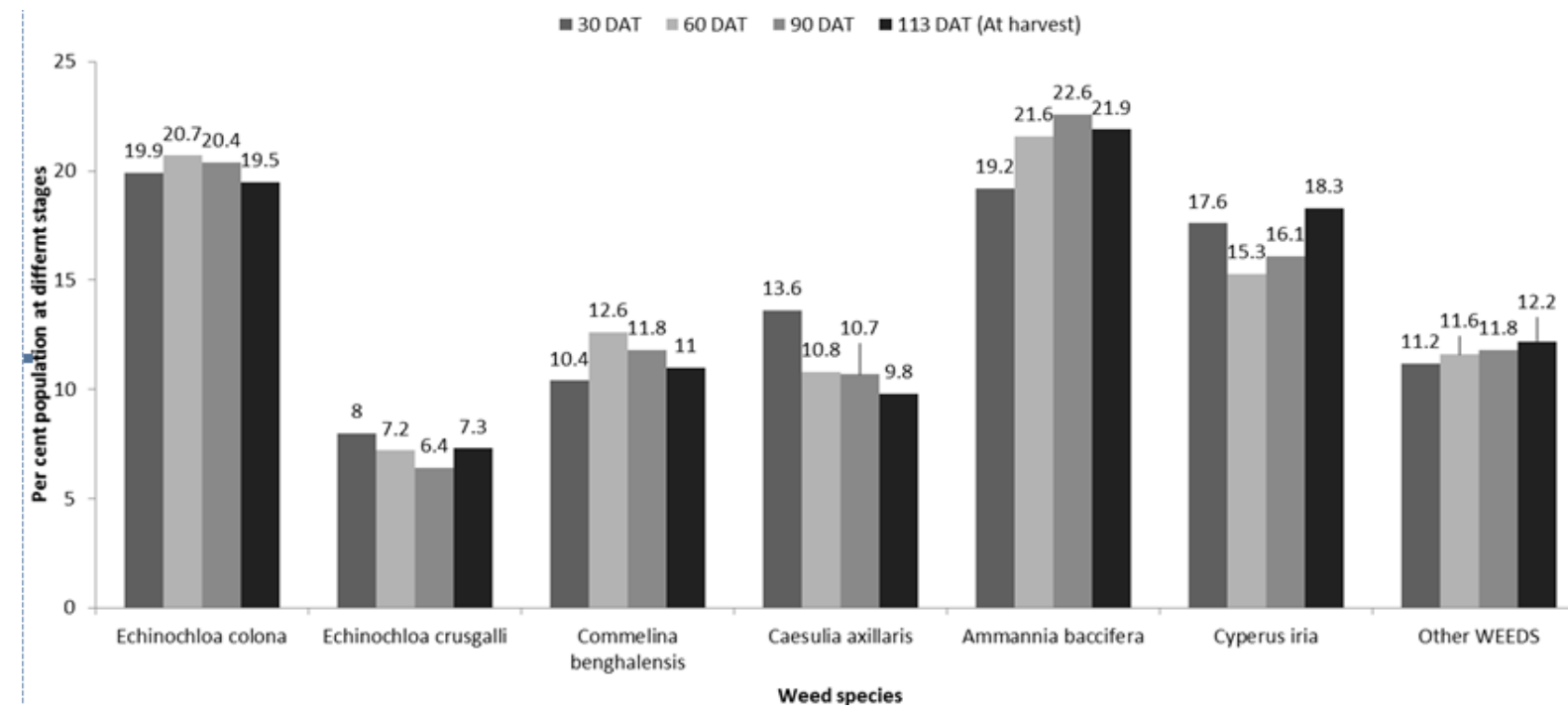

Fig. 1. Major weed species (per cent of total weeds) in weedy plots at different stages of rice crop growth.

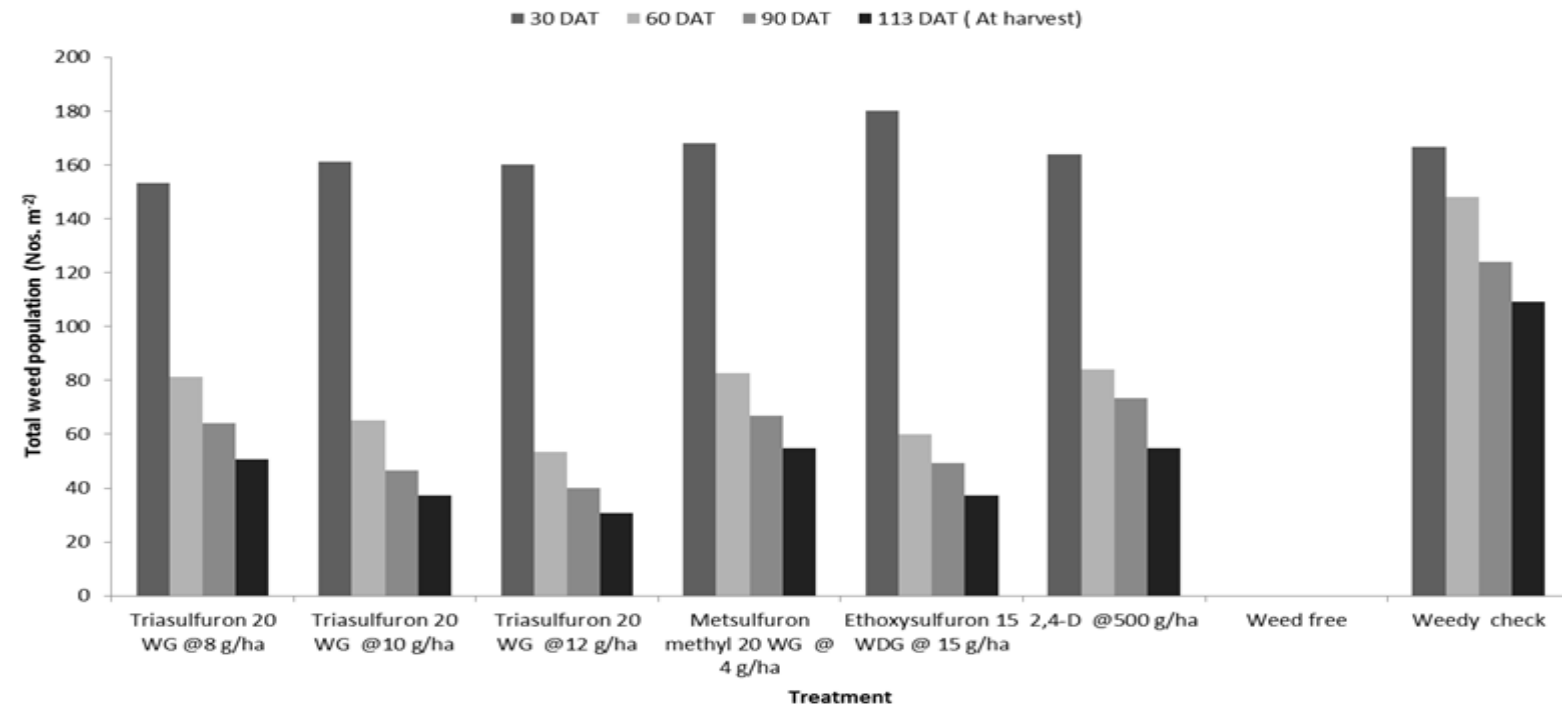

Fig. 2. Total weed population (Nos. $\mathrm{m}^{-2}$ ) at various stages of rice crop growth.

check to the total weed density was $19.2,21.6$, 22.6 and 21.9 per cent at 30,60, 90 and 113 DAT stages, respectively (Sridevi et al., 2013). Byahatti et al. (2010) reported that $A$. baccifera is a prevalent weed in rice fields and marshy localities all over India. The next superior weed found in weedy check site was $E$. colona which contributed 19.9, 20.7, 20.4 and 19.5 per cent respectively, to the total weed population at $30,60,90$ and 113 DAT stages of crop respectively. The effectiveness of diverse treatments on total weed density is shown in figure 2. All the weed control treatments caused depletion in the weed population at various stages of crop growth as compared to weedy check. Rice weeds treated with triasulfuron at $12 \mathrm{~g} \mathrm{ha}^{-1}$ got efficiently controlled at all the crop growth stages among all the herbicidal treatments. Rice weeds treated with ethoxysulfuron at $15 \mathrm{~g} \mathrm{ha}^{-1}$ at all the stages of crop growth and triasulfuron at $10 \mathrm{~g} \mathrm{ha}^{-1}$ at 90 and 113 days after transplanting was also found effective as can be seen by Table 1. Among the various herbicidal treatments, lowest weed density at 60 days after transplanting was observed (53.3 per square $\mathrm{m}$ ) with triasulfuron at $12 \mathrm{~g} \mathrm{ha}^{-1}$, which remained significantly superior at over all the other herbicidal treatments except ethoxysulfuron @ 15 $\mathrm{g} / \mathrm{ha}$ which did not differ significantly at $5 \%$ level of significance.

Effect on weed dry matter and weed control efficiency (WCE, \%): None of the herbicides except triasulfuron at 10 and $12 \mathrm{~g} \mathrm{ha}^{-1}$ at 60 and 90 DAT and triasulfuron at $8 \mathrm{~g} \mathrm{ha}^{-1}$ at 90 DAT were found potent for the reduction in dry matter of grassy weeds when compared with weedy check. In general, the dry matter of broad leaf weeds got increased upto 90 DAT except in case of triasulfuron at $12 \mathrm{~g} \mathrm{ha}^{-1}$ at all the stages of crop growth and triasulfuron at $10 \mathrm{~g} \mathrm{ha}^{-1}$ at 113 days stage, where complete control of broad leaf weeds was 
noticed. All the weed control measures resulted in significant reduction in dry matter of broad leaf weeds as compared to weedy check at 60 and 90 DAT at $5 \%$ level of significance. Triasulfuron at $10 \mathrm{~g} \mathrm{ha}^{-1}$ and $12 \mathrm{~g} \mathrm{ha}^{-1}$ were found superior to all the other herbicides at their respective selected rates for the control of broad leaf weeds. Dry matter production of sedges was significantly influenced by different weed control measures at 60 and 90 DAT at $5 \%$ level of significance. The dry matter production of sedges was found to increase upto 90 days stage of crop growth except in ethoxysulfuron at $15 \mathrm{~g} \mathrm{ha}^{-1}$ where sedges were completely controlled after its application. None of the herbicidal treatments except ethoxysulfuron at 15 $\mathrm{g} \mathrm{ha}^{-1}$ and triasulfuron at 10 or $12 \mathrm{~g} \mathrm{ha}^{-1}$ caused significant reduction in the dry matter of sedges. Metsulfuron methyl at $4 \mathrm{~g} \mathrm{ha}^{-1}$ being at par with 2,4- $D$ at $500 \mathrm{~g} \mathrm{ha}^{-1}$ recorded the highest dry matter of sedges at 60 and 90 DAT. The highest weed control efficiency was recorded under weed free condition $(100 \%)$ because of no weeds. Among the different rates of triasulfuron and other herbicides, the maximum weed control efficiency was observed with triasulfuron at $12 \mathrm{~g} \mathrm{ha}^{-1}$, which was closely followed by application of triasulfuron at $10 \mathrm{~g} \mathrm{ha}^{-1}$, ethoxysulfuron at $15 \mathrm{~g} \mathrm{ha}^{-1}$, triasulfuron at $8 \mathrm{~g} \mathrm{ha}^{-1}$ and 2,4-D at $500 \mathrm{~g} \mathrm{ha}^{-1}$. The lowest weed control efficiency was recorded with metsulfuron methyl at $4 \mathrm{~g} \mathrm{ha}^{-1}$ (Table 1).

Effect on rice grain yield: In our experiment, comparing the yields and weeds dry matter of weed free and weedy check treatments, we have found that the grain yield declined by $7.45 \mathrm{~kg} \mathrm{ha}^{-1}$ for every $\mathrm{g} \mathrm{m}^{-2}$ of dry matter produced by weeds. Pavithra and Poonguzhalan (2018) also reported that in abundance of weeds in rice competed with rice and the rice grain yield declined by $7.28 \mathrm{kgha}^{-1}$ for every $\mathrm{g} \mathrm{m}^{-2}$ of dry matter produced by weeds. All the weed control treatments produced significantly more grain yield than weedy check. The highest grain yield $\left(6513 \mathrm{~kg} \mathrm{ha}^{-1}\right)$ was recorded in weed free plots. None of the herbicidal treatments could produce grain yield equal to weed free condition. Among the herbicidal treatments, triasulfuron at $12 \mathrm{~g} \mathrm{ha}^{-1}$ produced the maximum grain yield of rice (5786 kg ha-1) which was significantly higher than all other treatments at $5 \%$ level of significance while the lowest grain yield was observed in metsulfuron methyl at $4 \mathrm{~g}^{-1}$ $\left(4417 \mathrm{~kg} \mathrm{ha}^{-1}\right)$. Krishnamurthy et al. (2007) observed that the lower dosage of triasulfuron @ $0.006 \mathrm{~kg}$ a.i/ha was not effective, while it's higher doses @ 0.009 and 0.012 kg a.i ha ${ }^{-1}$ were effec- tive and recorded higher grain yields. The grain yield of rice being low in triasulfuron at $8 \mathrm{~g} \mathrm{ha}^{-1}$ and was at par with 2, 4-D at $500 \mathrm{~g} \mathrm{ha}^{-1}$.

\section{Conclusion}

On the basis of present investigation, it may be concluded that among all the herbicides, application of triasulfuron at $12 \mathrm{~g} \mathrm{ha}^{-1}$ is most effective for control of weeds with weed control efficiency as $59.6 \%$ and for getting higher grain yield $(5786 \mathrm{~kg}$ $\left.\mathrm{ha}^{-1}\right)$. Rice weeds treated with ethoxysulfuron at $15 \mathrm{~g} \mathrm{ha}^{-1}$ at all the stages of crop growth and triasulfuron at $10 \mathrm{~g} \mathrm{ha}^{-1}$ at 90 and 113 days after transplanting were also found effective. Therefore , triasulfuron at $12 \mathrm{~g} \mathrm{ha}^{-1}$ should be opted for the better control of broad leaf weeds in transplanted rice.

\section{REFERENCES}

1. Byahatti, V.V., Vasantakumar, Pai, K. and D'Souza, M. (2010). Ammannia baccifera-Potential Medicinal Weed of Rice Fields - An Overview. Pharmacologyonline, 2: 776-781.

2. Clements F.E. University Publishing Company; 1905. Research Methods in Ecology.

3. Cochran and Cox, John Wiley \& Sons, Inc. (1957). Randomized Complete Block Designs, Adapted from Experimental Designs, 2nd ed.

4. Ferrero, A. and Tinarelli, A. (2007). Rice cultivation in the E.U. ecological conditions and agronomical practices. Pesticide Risk Assessment in Rice Paddies: Theory and Practice, pp. 1-24.

5. Krishnamurthy, P., Sreedevi, B. and Singh, S.P. (2007). Evaluation of combination weedicides in transplanted rice. Indian Journal of Plant Protection, 35(2): 331-334.

6. Mani, V. S., Chakraborty, T. K. and Gautam, K. C. (1973). Double hedge weed killers in peas. Indian Farming. 26(2): 80-83.

7. Nagarajan, R. and Chinnusamy, C. (2015). Evaluation of Bensulfuron methyl and butachlor herbicide tank mix on weed control and productivity of transplanted rice (Oryza sativa L.) The Ecoscan, 9(1\&2): 537-540.

8. Pavithra, M. and Poonguzhalan, R. (2018). Weed flora of aerobic rice and their effect on growth, yield and nutrient uptake by rice Oryza sativa in the coastal region of Karaikal of Puducherry. Journal of Applied and Natural Science ,10 (1): 397 -402.

9. Rekha, B., Jayadeva1, H. M., Kombali, G., Nagaraju, G. B. Mallikarjuna and Geethakumari, A. (2015). Growth and yield of aerobic rice grown under drip fertigation. The Ecoscan, 9(1\&2):435-437.

10.Sridevi, V., Jeyaraman, S., Chinnusamy, C. and Chellamuthu, V. (2013). Weed Management in lowland rice (Oryza Sativa L.) Ecosystem. International Journal of Agriculture Sciences and Research, 3 (3): 13-22. 